\title{
Environmental and health risk implications of air quality in the vicinity of the Port Harcourt Airport road dumpsite
}

\author{
Chukwu Okeah, G. O. ${ }^{1 *}$, Ihekwoaba, R. ${ }^{2}$ and Umediegwu, P. ${ }^{3}$ \\ ${ }^{1}$ Department of Geography and Environmental Management, University of Port Harcourt, River State, Nigeria. \\ ${ }^{2}$ Centre for Disaster Risk Management and Development Studies, University of Port Harcourt, River State, Nigeria. \\ ${ }^{3}$ Department of Environmental Resources Management, National Open University of Nigeria, Nigeria. \\ ${ }^{*}$ Corresponding author. Email: giftchukwuokeah@yahoo.com; gift.chukwuokeah@uniport.edu.ng
}

Copyright (C) 2021 Chukwu Okeah et al. This article remains permanently open access under the terms of the Creative Commons Attribution License 4.0, which permits unrestricted use, distribution, and reproduction in any medium, provided the original work is properly cited.

Received 19th May, 2020; Accepted 15th June, 2020

\begin{abstract}
This study examines environmental and health risk implications of air quality in the vicinity of the Port Harcourt airport road dumpsite. The study objectives are to determine air quality in the vicinity of the Port Harcourt airport road dumpsite of the municipal solid waste, examine the health risk implications of air quality in the study location, ascertain the environmental implications of the air quality in the vicinity of the dumpsite, and identify if there are variations in air quality in the different sections in the study location. Air quality was determined using standard operating procedures where samples were collected at the dump, $250 \mathrm{~m}$ and $500 \mathrm{~m}$ away from the dumpsite. The samples were collected in the morning, afternoon and evening hours of the same day. The samples collected from these locations were taken insitu amongst which are ( $\mathrm{Co}_{2}, \mathrm{CH}_{4}, \mathrm{O}_{2}, \mathrm{Co}, \mathrm{H}_{2} \mathrm{~S}, \mathrm{PM}-2.5$, $\mathrm{PM}-10$, $\mathrm{Ni}, \mathrm{Cr}$, Temperature and $\left.\mathrm{RH}\right)$. Survey questionnaire was administered, in order to complement the field results. Three hypotheses were also tested using ANOVA and the Chisquare analytical tool. The findings of the study show that Nickel and Chromium amongst other parameters were above the WHO standard limits. Therefore, the quality of air within the vicinity of the dumpsite is considered polluted. Consequently, URTI and skin rashes are the common ailments that are prevalent in the area of study. Thus, the municipal solid waste dumpsite constitutes both environmental and health implications to the human population within the vicinity of the Port Harcourt airport road dumpsite. In this regard, this study recommends that the citing of waste dump should be done in line with standard regulations and prohibits the development of residential settlements within $3 \mathrm{~km}$ radius from any dumpsite.
\end{abstract}

Keywords: Air quality, environmental and health risk, municipal solid waste dumpsite, Port Harcourt airport road, residential settlements.

\section{INTRODUCTION}

Air contamination is a noteworthy worry globally, and this has a genuine toxicological effect on human wellbeing and nature. It has various diverse emanation sources, yet engine vehicles and modern industrial practices contribute significantly to the pollution of air. As indicated by the World Health Organization (2014), six noteworthy air contaminations incorporate molecule contamination, ground-level ozone, carbon monoxide, sulfur oxides, nitrogen oxides, and lead. Long and momentary introduction to air suspended toxicants has an alternate toxicological effect on human including respiratory and cardiovascular maladies, neuropsychiatric entanglements, the eyes aggravation, skin illnesses, and long haul incessant sicknesses (Kevin, 2018).

The term breathing simply put connotes the act of ventilation of the lungs, a procedure which makes gas trade admission of oxygen into the body and the retrieval of carbon dioxide from the body into the earth increasingly productive. The development and constriction of the chest in people is the remotely obvious pointer of the gas trade process. Living creatures need to acquire oxygen so as to breathe properly (Millican and Barker, 1997). 
Piles of waste and rubbish have become normal sight in the state capitals and urban territories of Nigeria (Igwe et al., 2013). So far, untreated waste (metropolitan, mechanical and horticultural waste and so forth) are been discharged into the urban centres daily and this have brought about conditions which lead to extreme contamination and interruption of the normal environmental quality of the urban centres (Ezeifeoma, 2004 as cited in Njoku, 2015). The issue of waste has today turned out to be one of the genuine ecological issues confronting the most nations of the world because of its potential ability to cause contamination in the regular habitat (water, air, land), corrupt structures and landmarks (decrease in stylish esteem), and also represent a great deal of perils to human wellbeing and the characteristic assets of both social and monetary significance.

Brudtland Commission (2007) implied that contamination is a type of waste and a side effect of wastefulness in modern creation. So, if appropriately put, one can say that waste and contamination got connected at the hip since the nearness of the previous lead to the event of the last mentioned. In any case, air contamination is presentation of vaporous or suspended particulate issue into the environment from waste dumpsites that encroaches on the encompassing air quality. This could be as a result of characteristic or anthropogenic activities; although in nature, the composition of air is typically dictated by the amount of contamination.

Air pollution has been identified to be very poisonous to human and environmental health because it is deadly and its effects is felt by plants, animals and human and have the capacity to destroy the ecosystem which is a major anchor for human existence (Ogunji et al., 2004). Presently, waste management is a global issue which is not just limited to only urban centres but also in the rural areas especially in third world countries. It is an obvious fact that the establishment of waste dumpsites in some cases are not done following laid down procedure which at present have turned to a death trap especially for inhabitants around such areas (Agunwamba et al., 2016). This has brought about poor management of waste with the new trend of waste disposal along major roads and street, unapproved open dumpsites.

However, the introduction of materials either in solid or gaseous form into the atmosphere that is harmful to human health and undermines the quality of the environment is termed air pollution. This phenomenon arises from anaerobic process from waste dumpsites, harmful pollutants are released into the air and this could pose serious threat to life especially where the waste dumpsites are located within or close to residential apartments. According to Hassan and Abdullahi (2012), some of these pollutants include Carbon monoxide (CO), Sulphur dioxide $\left(\mathrm{SO}_{2}\right)$, Hydrogen sulphide $\left(\mathrm{H}_{2} \mathrm{~S}\right)$, Methane $\left(\mathrm{CH}_{4}\right)$, Nitrogen dioxide $\left(\mathrm{NO}_{2}\right)$, Ammonia $\left(\mathrm{NH}_{3}\right)$, Particulate Matter (PM10), and others.

Although it is well known fact that particulate matter to be specific can be seen amongst soot and dust but some others are not visible though they are present in the atmosphere, their composition is heightened by activities such as decomposed organic materials and waste from domestic sources as well as industrial activities which increases the threat to human life and environmental quality.

In relation to the above, Metz et al. (2007) stated that when natural parts of municipal solid waste (MSW) breaks down the outflow of some hurtful gases comprising of 50 $60 \%$ methane, $30-40 \%$ carbon dioxide, and $2-9 \%$ of different gases are discharged to the environment as overwhelming metals. Oxides of sulfur (SOX) and Nitrogen (NOX) can cause lung and cardiovascular illnesses, while suspended particulate matter has been accounted for to cause asthma, bronchitis, lung malignant growth, cardiovascular ailment, birth deformity and unexpected death (US-EPA, 1999; Rim-Rukeh, 2014).

It is therefore necessary owing to the challenges put forth by inappropriate waste management practices that studies such as this is timely as to protect life and enhance the quality of the environment, hence this study is concerned with examining environmental and health risk implications of air quality in the vicinity of the Port Harcourt airport road dumpsite. The key objectives of the study are to:

1. Determine the air quality in the vicinity of the Port Harcourt airport road dumpsite.

2. Examine the health risk implications of air quality in the study location.

3. Ascertain the environmental implications of the air quality in the vicinity of the Port Harcourt airport road dumpsite.

4. Identify if there are variations in air quality in the different sections in the study location.

The hypothesis which this study tried to verify is stated thus;

$\mathrm{H}_{01}$. There is no statistically significant variation in air quality in the different sections of the study area.

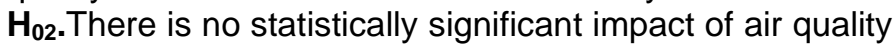
on environmental quality.

$\mathbf{H}_{03}$. There is no statistically significant impact of air quality on health of residents the vicinity of the Port Harcourt airport road dumpsite.

\section{MATERIALS AND METHODS}

\section{Study area}

The city of Port Harcourt is growing due to the high level of industrial activities which have generated high population. It is the capital city of Rivers State. The present day Port Harcourt is made up of four Local Government 


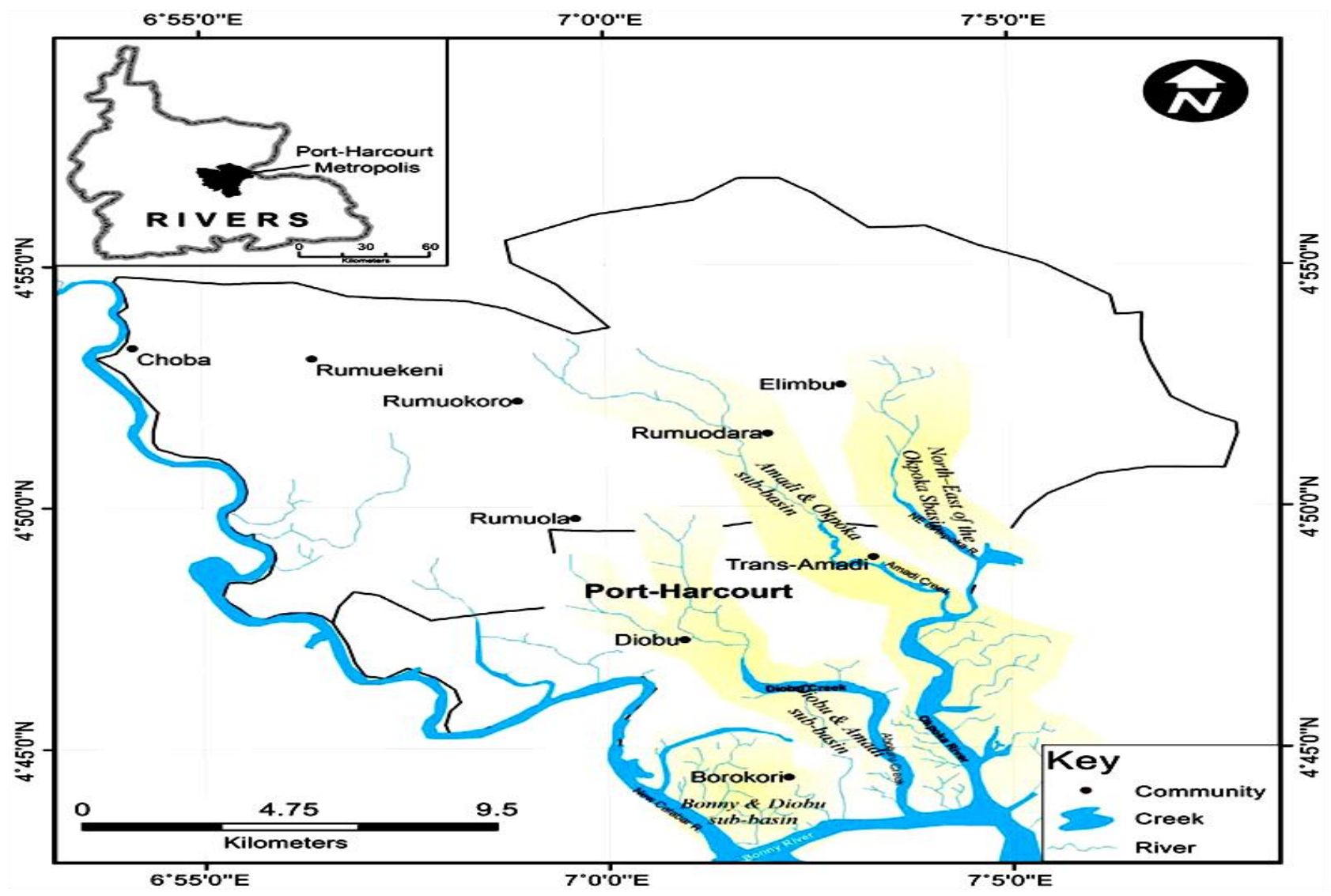

Figure 1. Showing study area.

Areas. The dumpsite is located along the new airport road by Special Anti-Robbery Squad (SARS) road Rumuagholu and boundary with Rukpoku, Aluu and Rumuosi communities all in the present day Obio/Akpor Local Government Area of Rivers State. The area geographically is located between latitude $4^{\circ} 45^{\prime} 0^{\prime \prime}$ and $4^{\circ} 55^{\prime} 0^{\prime \prime} \mathrm{N}$ and longitude $6^{\circ} 55^{\prime} 0^{\prime \prime}$ and $7^{\circ} 5^{\prime} 0^{\prime \prime} \mathrm{E}$. Its topography is novel and it is situated inside the waterfront fields which by its structure are of the sedimentary rocks of the Agbada, Akata and Benin formation. The climatic condition is the humid tropical atmosphere (Osuiwu and Ologunorisa, 1999) with a normal yearly temperature of $26.5^{\circ} \mathrm{C}$. The area experiences about $2476 \mathrm{~mm}$ of precipitation falls annually. January is the driest month in terms of precipitation with about $31 \mathrm{~mm}$ rain fall. Rainfall is mostly observed in the month of September, with an average of $401 \mathrm{~mm}$. About $370 \mathrm{~mm}$ difference exists between the driest month and the wettest. The area has a mean temperature of $24^{\circ} \mathrm{C}$, which varies within the year. The area is endowed with abundant sunshine due to its geographical location near the equator. The sun is vertically overhead throughout the year. Day light hours are more because of the long duration of solar radiation. The region is endowed with abundant natural resources such as oil and gas and forest for biodiversity conservation. The surface geology of the area is fairly stable without human interference such as drilling and oil exploration activities. The vegetation of the study area is the rainforest vegetation. This as shown in the Figure 1.

\section{Methods}

This study in line with the objectives adopted the quasiexperimental research design alongside the cross sectional research design. The primary and secondary data sources were used to illicit data for the study. Hence, in order to achieve the set goal for this study the data for this study concentrated more on the primary data sources which includes, field observation, air quality assessment, questionnaire administration and retrieval. Thereafter, secondary sources such as the World Health Organization standard for air quality was sought as well as works of other scholars in the related field.

The population of interest to the researcher owing to the nature of the area are those persons who reside within 1 $\mathrm{km}$ radius of the area, this the researcher was able to ascertain through recognizance survey on both sides of the dumpsite which are towards Rumuagholu and Rukpoku Communities. On the both sides, a total of 185 households were identified as the study population, thereafter the study adopted the use of $50 \%$ of the 

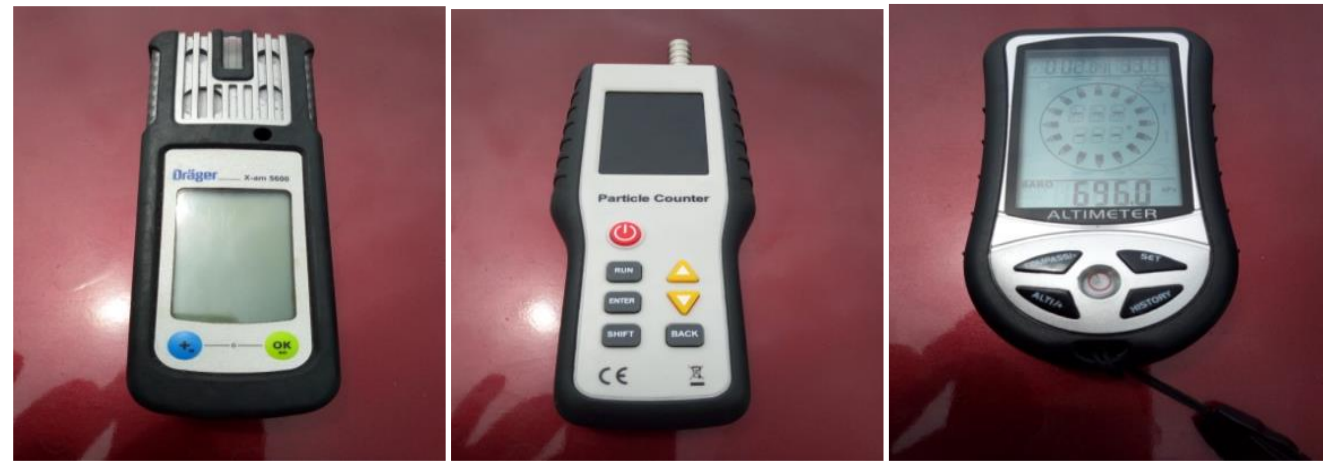

Plate 1. Drager-X-am5600 and Particle Counters.

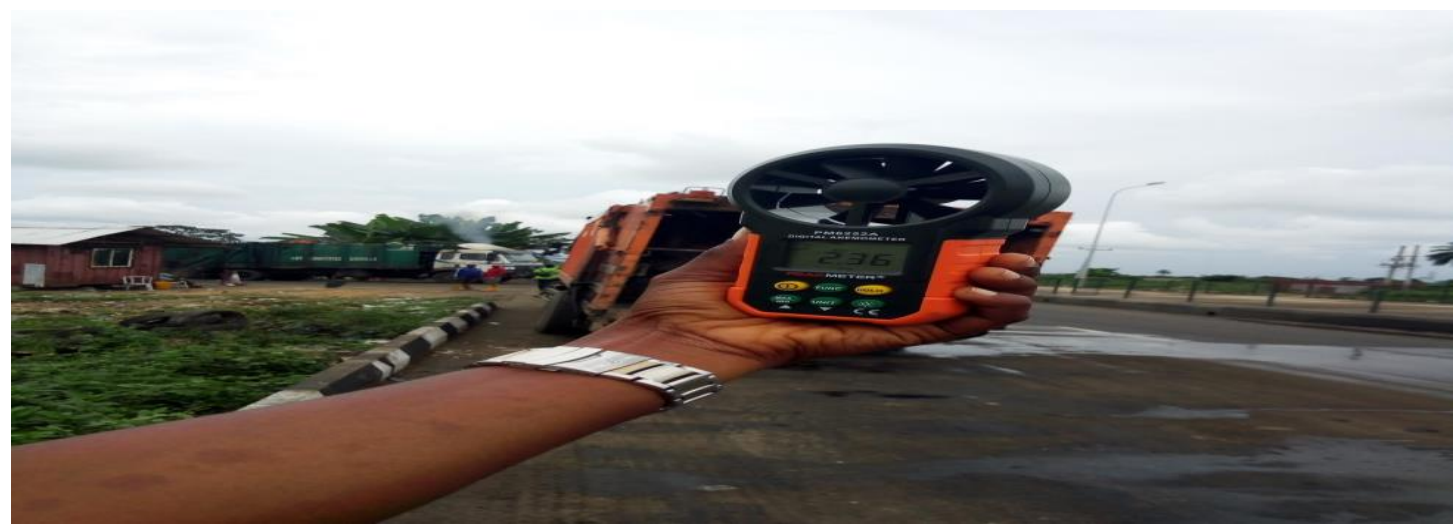

Plate 2. Measurement in process.

population which is statistically acceptable, Ezeh (2005) as cited in Ogoloma (2012). This gave the study a sample size of 93.5 approximately 94 households. Therefore, the sample size for the study is 94 households but attention was strictly given to house hold heads as the recipient of the questionnaire, which was administered through simple random sampling for only respondents who reside within 1 $\mathrm{km}$ radius of the area. The questionnaire was distributed with the support of field assistants and the recipient which are the household heads were asked to go through the questionnaire and respond adequately, hence they were allowed to keep the copies for a period of three days where after it was retrieved for analysis.

Air quality data was collected using air quality equipments and the parameters of interest to the study include $\mathrm{Co}_{2}, \mathrm{CH}_{4}, \mathrm{O}_{2}, \mathrm{CO}, \mathrm{PM}-2.5, \mathrm{Ni}, \mathrm{Cr}, \mathrm{PM}-10$, Temperature and $\mathrm{RH}$. The equipments includes; handheld SPM meter (Drager-X-am5600) and Particle Counter (Plates 1 and 2). The monitor uses light scatter to measure individual particles instead of clouds like other monitors. The particle information is then grouped into size ranges and converted to mass concentration over 4 minutes at a flow rate of $2.83 \mathrm{~L} / \mathrm{min}$ into measuring ranges of: $1-10$ micrograms per cubic metre mass concentration. Measurements were done by holding the sensor to a height of about two meters in the direction of the prevailing wind and readings recorded at stability. ASTM D1971/4691 was employed for the analysis of trace metals (Ni and $\mathrm{Cr}$ ) particulates using Shimadzu AA-6650 atomic absorption spectrophotometer. The study was carried out in November, 2019. Air sampling was carried out in three locations, the dumpsite, $250 \mathrm{~m}$ and $500 \mathrm{~m}$ away from the dumpsite and at intervals of 5 hours each for one day which are 6:30 am, 12:30 and 5:30 pm respectively.

\section{Data analyses}

Simple descriptive statistics was used in the analysis of the data, this includes the use of tables and percentages. Thereafter, the study hypotheses were tested using the Analysis of Variance statistical tool (ANOVA) for hypothesis one and the Chi-square statistical tool for hypotheses two and three of the study.

\section{RESULTS}

Table 1 shows the air quality in the vicinity of the airport road dumpsite at the morning hours, the record for the 
Table 1. Air quality data of the area in the morning hours.

\begin{tabular}{llccc}
\hline \multirow{2}{*}{$\mathbf{S} \mathbf{N}$} & \multirow{2}{*}{ Parameters } & \multicolumn{3}{c}{ Distance } \\
\cline { 3 - 5 } & & Dumpsite & $\mathbf{2 5 0} \mathbf{~}$ & $\mathbf{5 0 0} \mathbf{~ m}$ \\
\hline 1 & Wind Speed $(\mathrm{m} / \mathrm{s})$ & $1.93(\mathrm{max})$ & $1.82(\mathrm{max})$ & $1.50(\mathrm{max})$ \\
2 & Relative Humidity $(\%)$ & $0.60(\mathrm{~min})$ & $0.70(\mathrm{~min})$ & $0.50(\mathrm{~min})$ \\
3 & Temperature $\left({ }^{\circ} \mathrm{C}\right)$ & 82.4 & 73.5 & 68.4 \\
4 & $\mathrm{CO}_{2}(\% / \mathrm{vol})$ & 32.07 & 23.24 & 30.29 \\
5 & $\mathrm{CO}(\mathrm{ppm})$ & 0.05 & 0.04 & 0.03 \\
6 & $\mathrm{O}_{2}(\%)$ & 0.03 & 0.02 & 0.02 \\
7 & $\mathrm{PM} 2.5$ & 20.9 & 20.9 & 20.9 \\
8 & $\mathrm{PM} 10$ & 13 & 15 & 12 \\
9 & $\mathrm{Ni}\left(\mu \mathrm{gm}^{-3}\right)$ & 24 & 32 & 27 \\
10 & $\mathrm{Cr}\left(\mu \mathrm{gm}^{-3}\right)$ & 0.096 & 0.091 & 0.087 \\
\hline
\end{tabular}

Source: Field report (2019).

Table 2. Air quality of the area in the afternoon Hours.

\begin{tabular}{llccc}
\hline \multirow{2}{*}{$\mathbf{S} / \mathbf{N}$} & \multirow{2}{*}{ Parameters } & \multicolumn{3}{c}{ Distance } \\
\cline { 3 - 5 } 1 & \multirow{2}{*}{ Wind Speed $(\mathrm{m} / \mathrm{s})$} & $1.43(\mathrm{max})$ & $\mathbf{2 5 0} \mathbf{~}$ & $\mathbf{5 0 0} \mathbf{~}$ \\
\hline & Relative Humidity $(\%)$ & $0.40(\mathrm{~min})$ & $0.80(\mathrm{max})$ & $1.43(\mathrm{max})$ \\
2 & 72.7 & 67.5 & $0.40(\mathrm{~min})$ \\
3 & Temperature $\left({ }^{\circ} \mathrm{C}\right)$ & 31.07 & 30.24 & 65.3 \\
4 & $\mathrm{CO}_{2}(\% / \mathrm{vol})$ & 0.04 & 0.04 & 32.76 \\
5 & $\mathrm{CO}(\mathrm{ppm})$ & 0.02 & 0.02 & 0.03 \\
6 & $\mathrm{O}_{2}(\%)$ & 20.9 & 20.9 & 0.02 \\
7 & $\mathrm{PM} 2.5$ & 10 & 15 & 20.9 \\
8 & $\mathrm{PM} 10$ & 27 & 28 & 13 \\
9 & $\mathrm{Ni}\left(\mu \mathrm{gm}^{-3}\right)$ & 0.091 & 0.087 & 25 \\
10 & $\mathrm{Cr}\left(\mu \mathrm{gm}^{-3}\right)$ & 0.218 & 0.206 & 0.079 \\
\hline
\end{tabular}

Source: Field report (2019).

afternoon and evening were captured separately. It was observed that at the dumpsite, the result shows that wind speed on the maximum is $1.93 \mathrm{~m} / \mathrm{s}$ while on the minimum it is $0.60 \mathrm{~m} / \mathrm{s}$, at $250 \mathrm{~m}$ away, wind speed is $1.82 \mathrm{~m} / \mathrm{s}$ on the maximum and $0.70 \mathrm{~m} / \mathrm{s}$ on the minimum while at 500 $\mathrm{m}$ away, wind speed was observed to be $1.50 \mathrm{~m} / \mathrm{s}$ on the maximum and $0.50 \mathrm{~m} / \mathrm{s}$ on the minimum. In the case of relative humidity, it was observed that at the dump it was $82.4 \%$, at $250 \mathrm{~m}$ away it was observed to be $73.5 \%$ while at $500 \mathrm{~m}$ away it was observed to be $68.4 \%$. Measurements for temperature showed that at the dump, temperature was $32.07^{\circ} \mathrm{C}, 250 \mathrm{~m}$ away it was observed to be $23.24^{\circ} \mathrm{C}$ while at $500 \mathrm{~m}$ distance it was observed to be $30.29^{\circ} \mathrm{C}$. Measurements for $\mathrm{CO}_{2}$ showed that at the dump, $\mathrm{CO}_{2}$ recorded $0.05 \mathrm{ppm}$, at $250 \mathrm{~m}$ away it was $0.04 \mathrm{ppm}$ while at $500 \mathrm{~m}$ away its record was $0.03 \mathrm{ppm}$. In the same vein, measurements for $\mathrm{CO}$ showed that at the dump, it was $0.02 \mathrm{ppm}$ and this was the same in the case of $250 \mathrm{~m}$ and that of $500 \mathrm{~m}$ away respectively. Measurement for $\mathrm{O}_{2}$ also showed that at the dump the reading was $2.09 \%$ and this is the same for $250 \mathrm{~m}$ and $500 \mathrm{~m}$ away respectively.

Measurements for PM 2.5 showed that at the dumpsite,

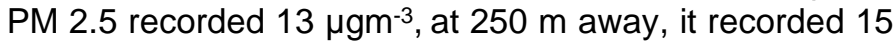

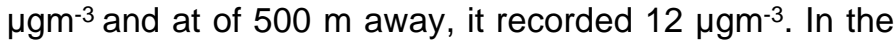
case of PM 10, the Table 1 showed that at the dump PM

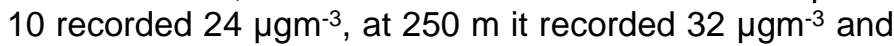
at $500 \mathrm{~m}$ away it recorded $27 \mathrm{\mu gm}^{-3}$. Nickel measurements as shown on the Table 1 revealed that at the dumpsite, it had a value of $0.096 \mathrm{\mu gm}^{-3}$, at $250 \mathrm{~m}$ away, it recorded

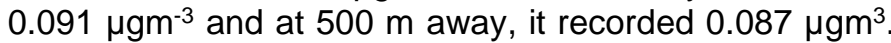
Lastly, chromium measurements in the dump showed a value of $0.228 \mu^{-3}$, at $250 \mathrm{~m}$ away, it showed a value of $0.201 \mathrm{\mu gm}^{-3}$ and at $500 \mathrm{~m}$ away, it showed a value of 0.197 $\mu \mathrm{gm}^{-3}$.

The Table 2 expresses the air quality of the vicinity of the airport road dumpsite in the afternoon hours, it is observed that at the dumpsite measurement taken shows that wind speed on the maximum was $1.43 \mathrm{~m} / \mathrm{s}$ while on the 
Table 3. Air quality of the area in the evening hours.

\begin{tabular}{|c|c|c|c|c|}
\hline \multirow{2}{*}{$\mathbf{S} / \mathbf{N}$} & \multirow{2}{*}{ Parameters } & \multicolumn{3}{|c|}{ Distance } \\
\hline & & Dumpsite & $250 \mathrm{~m}$ & $500 \mathrm{~m}$ \\
\hline \multirow{2}{*}{1} & \multirow{2}{*}{ Wind Speed $(\mathrm{m} / \mathrm{s})$} & $1.15(\max )$ & $1.40(\max )$ & $1.0(\max )$ \\
\hline & & $0.20(\min )$ & $0.20(\mathrm{~min})$ & $0.80(\mathrm{~min})$ \\
\hline 2 & Relative Humidity (\%) & 79.2 & 81.8 & 88.6 \\
\hline 3 & Temperature $\left({ }^{\circ} \mathrm{C}\right)$ & 27.9 & 27.18 & 26.73 \\
\hline 4 & $\mathrm{CO}_{2}(\% / \mathrm{vol})$ & 0.04 & 0.04 & 0.04 \\
\hline 5 & $\mathrm{CO}(\mathrm{ppm})$ & 0.02 & 0.02 & 0.02 \\
\hline 6 & $\mathrm{O}_{2}(\%)$ & 20.9 & 20.9 & 20.9 \\
\hline 7 & PM 2.5 & 3 & 4 & 5 \\
\hline 8 & PM 10 & 17 & 18 & 26 \\
\hline 9 & $\mathrm{Ni}\left(\mu \mathrm{gm}^{-3}\right)$ & 0.095 & 0.098 & 0.087 \\
\hline 10 & $\mathrm{Cr}\left(\mu \mathrm{gm}^{-3}\right)$ & 0.223 & 0.210 & 0.192 \\
\hline
\end{tabular}

Source: Field report (2019).

minimum it was $0.40 \mathrm{~m} / \mathrm{s}$, at $250 \mathrm{~m}$ distance from the dump wind speed was $1.72 \mathrm{~m} / \mathrm{s}$ on the maximum and $0.80 \mathrm{~m} / \mathrm{s}$ on the minimum while at a distance of $500 \mathrm{~m}$ wind speed was observed to be $1.43 \mathrm{~m} / \mathrm{s}$ on the maximum and 0.40 $\mathrm{m} / \mathrm{s}$ on the minimum.

In the case of relative humidity, it is observed to be $72.7 \%$ at the dumpsite, at the distance of $250 \mathrm{~m}$, it was observed to be $67.5 \%$ while at the distance of $500 \mathrm{~m}$ it was observed to be $65.3 \%$. Measurements for temperature showed that at the dump, temperature was $31.07^{\circ} \mathrm{C}$, at the distance of $250 \mathrm{~m}$, it was observed to be $30.24^{\circ} \mathrm{C}$ while at the distance of $500 \mathrm{~m}$ it was observed to be $32.76^{\circ} \mathrm{C}$.

Measurements for $\mathrm{CO}_{2}$ showed that at the dump, $\mathrm{CO}_{2}$ recorded $0.04 \mathrm{ppm}$, at the distance of $250 \mathrm{~m}$, it was 0.04 ppm while at the distance of $500 \mathrm{~m}$, its record was 0.03 $\mathrm{ppm}$. In the same vein, measurements for $\mathrm{CO}$ showed that at the dump, CO was $0.02 \mathrm{ppm}$ and this was the same in the case of the distance of $250 \mathrm{~m}$ and that of $500 \mathrm{~m}$ respectively. Measurement for $\mathrm{O}_{2}$ also showed that at the dump the reading was $2.09 \%$ and this is the same for 250 and $500 \mathrm{~m}$ distance respectively.

Measurements for PM 2.5 showed that at the dump PM 2.5 recorded $10 \mathrm{\mu gm}^{-3}$, at the distance of $250 \mathrm{~m}$, it recorded

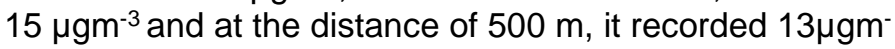
3 . In the case of PM 10, the Table 2 showed that at the

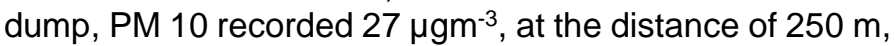
it recorded $28 \mathrm{\mu gm}^{-3}$ and at the distance of $500 \mathrm{~m}$, it recorded $25 \mathrm{\mu gm}^{-3}$. Nickel measurements as shown on the Table 2 revealed that at the dump, a value of $0.091 \mu^{-3} \mathrm{gm}^{-3}$ was recorded, at the distance of $250 \mathrm{~m}$, it recorded 0.087

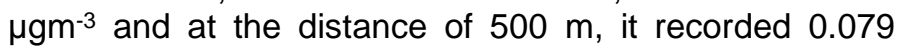
${\mu \mathrm{gm}^{3}}^{3}$. Lastly, chromium measurements in the dump

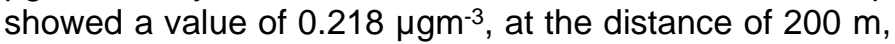
it showed a value of $0.206 \mathrm{\mu gm}^{-3}$ and at the distance of 500 $\mathrm{m}$, it showed a value of $0.201 \mathrm{\mu gm}^{-3}$.

The Table 3 expresses the mean air quality of the vicinity of the airport road dumpsite at the evening hours, it was observed that at the dumpsite, measurement taken shows that wind speed on the maximum was $1.15 \mathrm{~m} / \mathrm{s}$ while on the minimum it was $0.20 \mathrm{~m} / \mathrm{s}$, at $250 \mathrm{~m}$ distance from the dump, wind speed was $1.40 \mathrm{~m} / \mathrm{s}$ on the maximum and 0.20 $\mathrm{m} / \mathrm{s}$ on the minimum while at a distance of $500 \mathrm{~m}$ wind speed was observed to be $1.0 \mathrm{~m} / \mathrm{s}$ on the maximum and $0.80 \mathrm{~m} / \mathrm{s}$ on the minimum. In the case of relative humidity, it was observed at the dumpsite a relative humidity of $79.2 \%$, at the distance of $250 \mathrm{~m}$, it was observed to be $81.8 \%$ while at the distance of $500 \mathrm{~m}$, it was observed to be $88.6 \%$. Measurements for temperature showed that at the dump, temperature was $27.9^{\circ} \mathrm{C}$, at the distance of 250 $\mathrm{m}$, it was observed to be $27.18^{\circ} \mathrm{C}$ while at the distance of $500 \mathrm{~m}$, it was observed to be $26.73^{\circ} \mathrm{C}$.

Measurements for $\mathrm{CO}_{2}$ showed that at the dump, $\mathrm{CO}_{2}$ recorded $0.04 \mathrm{ppm}$, at the distance of $250 \mathrm{~m}$, it was 0.04 ppm while at the distance of $500 \mathrm{~m}$, its record was 0.04 $\mathrm{ppm}$. In the same vein, measurements for $\mathrm{CO}$ showed that at the dump, CO was $0.02 \mathrm{ppm}$ and this was the same in the case of the distance of $250 \mathrm{~m}$ and that of $500 \mathrm{~m}$ respectively. Measurement for $\mathrm{O}_{2}$ also showed that at the dump the reading was $2.09 \%$ and this is the same for 250 and $500 \mathrm{~m}$ distance respectively.

Measurements for PM 2.5 showed that at the dump, PM

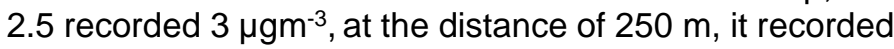
$4{\mu \mathrm{gm}^{-3}}^{3}$ and at the distance of $500 \mathrm{~m}$, it recorded $5 \mu \mathrm{gm}^{-3}$. In the case of PM 10, the Table 3 showed that at the dump,

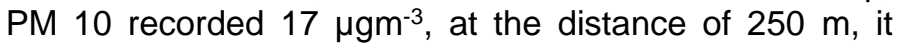
recorded $18 \mathrm{\mu gm}^{-3}$ and at the distance of $500 \mathrm{~m}$, it recorded $26 \mu^{-3} \mathrm{gm}^{-3}$. Nickel measurements as shown in Table 3 revealed that at the dump, a value of $0.095{\mu \mathrm{gm}^{-3}}^{-3}$ was recorded, at the distance of $250 \mathrm{~m}$, it recorded 0.098

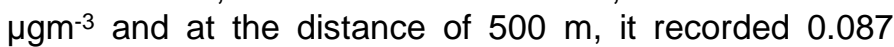
${\mu \mathrm{gm}^{3}}^{3}$. Lastly, chromium measurements in the dump

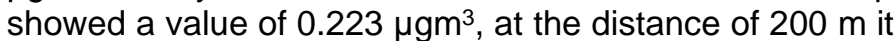
showed a value of $0.210{\mu \mathrm{gm}^{3}}^{3}$ and at the distance of 500 $\mathrm{m}$ it showed a value of $0.192 \mu \mathrm{gm}^{3}$.

Table 4 shows the mean air quality data of the dumpsite from the different sampling points. Wind speed measure- 
Table 4. Mean air quality data of the area.

\begin{tabular}{llccc}
\hline \multirow{2}{*}{$/ \mathbf{N}$} & \multirow{2}{*}{ Parameters } & \multicolumn{3}{c}{ Distance } \\
\cline { 3 - 5 } & & Dump & $\mathbf{2 5 0 \mathbf { m }}$ & $\mathbf{5 0 0 \mathbf { m }}$ \\
\hline \multirow{2}{*}{ Wind Speed $(\mathrm{m} / \mathrm{s})$} & $1.50(\mathrm{max})$ & $1.65(\mathrm{max})$ & $1.31(\mathrm{max})$ \\
2 & Relative Humidity $(\%)$ & $0.40(\mathrm{~min})$ & $0.33(\mathrm{~min})$ & $0.56(\mathrm{~min})$ \\
3 & Temperature $\left({ }^{\circ} \mathrm{C}\right)$ & 78.1 & 74.2 & 74.1 \\
4 & $\mathrm{CO}_{2}(\% / \mathrm{vol})$ & 30.3 & 26.8 & 29.9 \\
5 & $\mathrm{CO}(\mathrm{ppm})$ & 0.04 & 0.04 & 0.03 \\
6 & $\mathrm{O}_{2}(\%)$ & 0.02 & 0.02 & 0.02 \\
7 & $\mathrm{PM} 2.5$ & 20.9 & 20.9 & 20.9 \\
8 & $\mathrm{PM} 10$ & 8.66 & 11.3 & 10 \\
9 & $\mathrm{Ni}\left(\mu \mathrm{gm}^{-3}\right)$ & 22.7 & 26 & 26 \\
10 & $\mathrm{Cr}\left(\mu \mathrm{gm}^{-3}\right)$ & 0.094 & 0.092 & 0.084 \\
\hline
\end{tabular}

Source: Field report (2019).

Table 5. Mean air quality of the area and World Organization standard for air quality.

\begin{tabular}{|c|c|c|c|c|c|}
\hline \multirow{2}{*}{$S / N$} & \multirow{2}{*}{ Parameters } & \multicolumn{3}{|c|}{ Distance } & \multirow{2}{*}{ WHO } \\
\hline & & At point & $250 \mathrm{~m}$ & $500 \mathrm{~m}$ & \\
\hline \multirow{2}{*}{1} & \multirow{2}{*}{ Wind Speed $(\mathrm{m} / \mathrm{s})$} & $1.50(\max )$ & $1.65(\max )$ & 1.31 (max) & \\
\hline & & 0.40 (min) & $0.33(\mathrm{~min})$ & 0.56 (min) & NA \\
\hline 2 & Relative Humidity (\%) & 78.1 & 74.2 & 74.1 & NA \\
\hline 3 & Temperature $\left({ }^{\circ} \mathrm{C}\right)$ & 30.3 & 26.8 & 29.9 & NA \\
\hline 4 & $\mathrm{CO}_{2}(\% / \mathrm{vol})$ & 0.04 & 0.04 & 0.03 & N.A \\
\hline 5 & $\mathrm{CO}(\mathrm{ppm})$ & 0.02 & 0.02 & 0.02 & dg \\
\hline 6 & $\mathrm{O}_{2}(\%)$ & 20.9 & 20.9 & 20.9 & N.A \\
\hline 7 & PM 2.5 & 8.66 & 11.3 & 10 & d 25 \\
\hline 8 & PM 10 & 22.7 & 26 & 26 & d70 \\
\hline 9 & $\mathrm{Ni}\left(\mu \mathrm{gm}^{-3}\right)$ & 0.094 & 0.092 & 0.084 & f0.01 \\
\hline 10 & $\operatorname{Cr}\left(\mu \mathrm{gm}^{-3}\right)$ & 0.223 & 0.205 & 0.198 & ${ }^{\mathrm{f}} 0.02$ \\
\hline
\end{tabular}

Source: Field report (2019).

ment reveals that at the dump, the record for wind speed is $1.50 \mathrm{~m} / \mathrm{s}$ on the maximum and $0.40 \mathrm{~m} / \mathrm{s}$ on the minimum, at the distance of $250 \mathrm{~m}$, wind speed record was $165 \mathrm{~m} / \mathrm{s}$ on the maximum and $0.33 \mathrm{~m} / \mathrm{s}$ on the minimum while at the distance of $500 \mathrm{~m}$, the record was $1.31 \mathrm{~m} / \mathrm{s}$ on the maximum and $0.56 \mathrm{~m} / \mathrm{s}$ on the minimum. Wind speed was higher at the distance of $250 \mathrm{~m}$ away from the dumpsite.

Relative Humidity recorded shows that relative humidity is higher at the dumpsite as it recorded a value of $78.1 \%$ which is far more than the value recorded at the distance of $250 \mathrm{~m}$ and $500 \mathrm{~m}$ which accounts for $74.2 \%$ and $74.1 \%$ respectively. Temperature report revealed that the dump recorded the highest amongst others with a temperature value of $30.3^{\circ} \mathrm{C}$, while at the distance of $250 \mathrm{~m}$ had a temperature value of 26.8 and $29.9^{\circ} \mathrm{C}$ for the distance of $500 \mathrm{~m}$.

$\mathrm{CO}_{2}$ had a mean value of $0.04 \mathrm{ppm}$ at the dumpsite, same at the distance of $250 \mathrm{~m}$ way from the dump and 0.03 at the distance of $500 \mathrm{~m}$ away from the dump. In the case of $\mathrm{CO}$ in the three identified sampling points, the same mean value of 0.02 was recoded. For $\mathrm{O}_{2}$, a mean value of $20.9 \%$ was observed in all the sampling points.

Particulate matter observation revealed differently from the above, PM 2.5 at the dumpsite had a mean value of $8.66 \mu \mathrm{m}, 11.3 \mu \mathrm{m}$ at a distance of $250 \mathrm{~m}$ away from the dumpsite and $10 \mu \mathrm{m}$ at the distance of $500 \mathrm{~m}$ away from the dumpsite. PM 10 on the other hand had a mean value of $22.7 \mu \mathrm{m}$ at dumpsite, $26 \mu \mathrm{m}$ at a distance of $250 \mathrm{~m}$ away from the dumpsite and $26 \mu \mathrm{m}$ at a distance of $500 \mathrm{~m}$ away from the dumpsite.

$\mathrm{Ni}$ as shown on the Table 4 had a mean value of 0.094

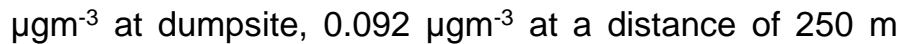
away from the dumpsite and $0.084{\mu \mathrm{gm}^{-3}}^{-3}$ at a distance of $500 \mathrm{~m}$ away from the dumpsite. In the case of $\mathrm{Cr}$, it had at

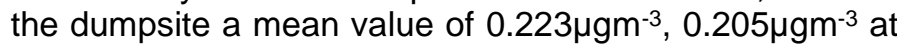
a distance of $250 \mathrm{~m}$ and $0.198{\mu \mathrm{gm}^{-3}}^{3}$ at a distance of 500 $\mathrm{m}$ away from the dumpsite.

The Table 5 shows air quality of the airport road dumpsite in relation to World Health organization standard for air quality. From the Table 5, some of the parameters 
of interest are not applicable in the WHO enlisted standards. The Table 5 further shows that amongst all the parameters listed only Nickel and Chromium have values more than the set standard in all the three sample locations on an annual basis.

\section{Socio-demographics of respondents}

Table 6 shows questionnaire administration and retrieval, as observed, a total of 94 respondents where sampled for the study only 89 of them returned back the questionnaire fully filled and complete which was used for the analysis of the study.

Table 7 shows the socio demographic characteristics of the respondents in the study. A total of 73 male which represents $77.7 \%$ of the study population participated in the study as against 21 female which represent $22.3 \%$ of the population. Age of respondents as observed was more amongst the age range of 36 to 45 years with a total of 44 respondents which represents $46.8 \%$ of the study population; this was followed by the age range of 25 to 35 with a total of 29 respondents which represents $30.9 \%$ of the study population and lastly by those in the age range of 45 and above with a total population of 21 respondents which represents $22.3 \%$ of the study population.

The occupation of respondents showed that artisans were more with a total population of 35 respondents which represents $37.2 \%$ of the study population; this was followed by traders with a total of 32 respondents which represents $34.0 \%$ of the study population and civil servants with a population of 27 respondents which represents $28.7 \%$ of the study population.

Educational attainment of respondents as observed showed that more of the respondents have attained secondary education, this accounts for 53 respondents which represents $56.4 \%$ of the study population; this is followed by primary school attainment with a population of 20 respondents which represents $21.3 \%$ of the study population, tertiary education attainment had a total of 19 respondents which represents $20.2 \%$ of the study population and lastly those without formal education were 2 respondents which represents $2.12 \%$ of the study population.

\section{Environmental implications of the air quality in the vicinity of the Port Harcourt airport road dumpsite}

This section of the study reveals the perception of the respondents in relation to their perceived implications of air quality in the vicinity of the Port Harcourt airport road dumpsite. Table 8 shows that on the issue of waste dumpsite in the area influencing air quality which affects human health, 37 respondents which represent $39.4 \%$ of the study population strongly agreed, 28 respondents which represents $29.8 \%$ of the study population agreed, 16 respondents which represents $17.0 \%$ of the study
Table 6. Questionnaire administration and retrieval.

\begin{tabular}{lcc}
\hline Response & Frequency & Percentage (\%) \\
\hline Number Administered & 94 & 100 \\
Number Collected & 89 & 94.7 \\
\hline
\end{tabular}

Source: Field report (2019).

Table 7. Socio demographic characteristics of the respondents.

\begin{tabular}{lc}
\hline Socio demographic characteristics & Respondents \\
\hline Sex & 73 \\
Male & 21 \\
Female & 94 \\
Total & \\
& \\
Age & \\
$25-35$ & 29 \\
$36-45$ & 44 \\
45 and above & 21 \\
Total & 94 \\
& \\
Occupation & \\
Trading & 32 \\
Civil Servant & 27 \\
Artisan & 35 \\
Total & 94 \\
& \\
Level of Education & \\
Primary & \\
Secondary & 20 \\
Tertiary & 53 \\
No formal Education & 19 \\
Total & 2 \\
Soure: Fild teport & 94 \\
\hline
\end{tabular}

Source: Field report (2019).

Table 8. Waste dumpsite in the area influences air quality which affects Human health.

\begin{tabular}{lcc}
\hline Response & Frequency & Percentage \\
\hline Strongly Agreed & 37 & 39.4 \\
Agreed & 28 & 29.8 \\
Disagreed & 16 & 17.0 \\
Strongly disagreed & 13 & 13.8 \\
Total & 94 & 100 \\
\hline
\end{tabular}

Source: Field report (2019).

population disagreed while 13 respondents which represents $13.8 \%$ of the study population strongly disagreed.

Table 9 shows the ailments associated with waste dump environment, here 27 respondents which represent $28.7 \%$ 
Table 9. Ailments associated with air quality around waste dump environment.

\begin{tabular}{lcc}
\hline Response & Frequency & Percentage \\
\hline URTI & 27 & 28.7 \\
Rashes & 32 & 34.0 \\
Cough/Catarrh & 20 & 21.3 \\
Eye Irritation & 17 & 18.1 \\
Total & 94 & 100 \\
\hline
\end{tabular}

Source: Field report (2019).

Table 10. Air quality influences environmental quality in the waste dump vicinity.

\begin{tabular}{lcc}
\hline Response & Frequency & Percentage \\
\hline Strongly Agreed & 58 & 61.7 \\
Agreed & 27 & 28.7 \\
Disagreed & 7 & 7.4 \\
Strongly Disagreed & 2 & 2.2 \\
Total & 94 & 100 \\
\hline
\end{tabular}

Source: Field report (2019).

Table 11. The presence of waste dump in the vicinity is an environmental nuisance.

\begin{tabular}{lcc}
\hline Response & Frequency & Percentage \\
\hline Strongly Agreed & 27 & 28.7 \\
Agreed & 31 & 32.9 \\
Disagreed & 21 & 22.3 \\
Strongly Disagreed & 15 & 15.9 \\
Total & 94 & 100 \\
\hline
\end{tabular}

Source: Field report (2019).

of the study population consented to upper respiratory tracts infection, 32 respondents which represents $34.0 \%$ of the study population agreed that it is rashes, 20 respondents which represents $21.3 \%$ of the study population stated that it is cough/catarrh while 17 respondents which represents $18.1 \%$ of the study population consented to eye irritation.

Table 10 shows the perception of the people to air quality as influencing environmental quality in the vicinity of the dump, 58 respondents which represent $61.7 \%$ of the study population agreed, 27 respondents which represents $28.7 \%$ of the study population agreed, 7 respondents which represents $7.4 \%$ of the study population disagreed while 2 respondents which represents $2.2 \%$ of the study population strongly disagreed .

Table 11 shows that on the issue of the presence of waste dump in the vicinity is an environmental nuisance, 27 respondents which represent $28.7 \%$ of the study population strongly agreed, 31 respondents which represents $32.9 \%$ of the study population agreed, 21 respon-
Table 12. The waste dump has deformed the land in the area.

\begin{tabular}{lcc}
\hline Response & Frequency & Percentage \\
\hline Strongly Agreed & 42 & 44.7 \\
Agreed & 22 & 23.4 \\
Disagreed & 17 & 18.1 \\
Strongly Disagreed & 13 & 13.8 \\
Total & 94 & 100 \\
\hline
\end{tabular}

Source: Field report (2019).

Table 13: Rental and Property value in the vicinity is influenced by the waste dump.

\begin{tabular}{lcc}
\hline Response & Frequency & Percentage \\
\hline Strongly Agreed & 32 & 34.0 \\
Agreed & 19 & 20.2 \\
Disagreed & 23 & 24.5 \\
Strongly Disagreed & 20 & 21.3 \\
Total & 94 & 100 \\
\hline
\end{tabular}

Source: Field report (2019).

dents which represents $22.3 \%$ of the study popu-lation disagreed while 15 respondents which represents $15.9 \%$ of the study population strongly disagreed.

Table 12 shows that on the issue that the waste dump has deformed the land in the area, 42 respondents which represent $44.7 \%$ of the study population strongly agreed, 22 respondents which represents $23.4 \%$ of the study population agreed, 17 respondents which represents $18.1 \%$ of the study population disagreed while 13 respondents which represents $13.8 \%$ of the study population strongly disagreed.

Table 13 shows that on the issue of rental and property value in the vicinity is influenced by the waste dump, 32 respondents which represent $34.0 \%$ of the study population strongly agreed, 19 respondents which represents $20.2 \%$ of the study population agreed, 23 respondents which represents $24.5 \%$ of the study population disagreed while 20 respondents which represents $21.3 \%$ of the study population strongly disagreed

Table 14 shows that on the issue of the waste dump defacing the aesthetics of the area, 51 respondents which represent $54.3 \%$ of the study population strongly agreed, 26 respondents which represents $27.7 \%$ of the study population agreed, 13 respondents which represents $13.8 \%$ of the study population disagreed while 4 respondents which represents $4.2 \%$ of the study population strongly disagreed.

\section{Hypotheses testing}

The first study hypothesis $\left(\mathrm{H}_{01}\right)$ states that there is no statistically significant variation in air quality in the different 
Table 14. The presence of the waste dump has defaced the aesthetics of the area.

\begin{tabular}{lcc}
\hline Response & Frequency & Percentage \\
\hline Strongly Agreed & 51 & 54.3 \\
Agreed & 26 & 27.7 \\
Disagreed & 13 & 13.8 \\
Strongly disagreed & 4 & 4.2 \\
Total & 94 & 100 \\
\hline
\end{tabular}

Source: Field report (2019).

Table 15. Result of ANOVA for variation in air quality in the different sections of the Area.

\begin{tabular}{lcccccc}
\hline Source of variation & SS & Df & MS & F & P-value & F crit \\
\hline Between Groups & 0.134438 & 2 & 0.067219 & \multirow{2}{*}{0.000127} & \multirow{2}{*}{0.999873} & \multirow{2}{*}{3.31583} \\
Within Groups & 15910.15 & 30 & 530.3384 & & & \\
Total & 15910.29 & 32 & & & & \\
\hline
\end{tabular}

Table 16. Chi-Square analysis table for impact of air quality on environmental quality

\begin{tabular}{lccccc}
\hline Response & Observed & Expected & O-E & $\mathbf{O}^{2} \mathbf{E}^{2}$ & $\mathbf{O}^{-E^{2} / \mathbf{E}}$ \\
\hline Strongly Agreed & 58 & 18.8 & 39.2 & 1536.6 & 81.7 \\
Agreed & 27 & 18.8 & 8.2 & 67.2 & 3.57 \\
Disagreed & 7 & 18.8 & -11.8 & 139.2 & 7.4 \\
Strongly Disagreed & 2 & 18.8 & -16.8 & 282.2 & 15.0 \\
$\mathbf{X}^{2}$ & & & & & 107.67 \\
\hline
\end{tabular}

Table 17. Chi-Square analysis table for impact of air quality on health

\begin{tabular}{lccccc}
\hline Response & Observed & Expected & O-E & $\mathbf{O}^{-E^{2}}$ & $\mathbf{O}^{-E^{2} / \mathbf{E}}$ \\
\hline Strongly Agreed & 27 & 18.8 & 8.2 & 67.2 & 3.57 \\
Agreed & 32 & 18.8 & 13.2 & 174.2 & 9.26 \\
Disagreed & 20 & 18.8 & 1.2 & 1.44 & 0.07 \\
Strongly Disagreed & 17 & 18.8 & -1.8 & 3.24 & 0.18 \\
X $^{2}$ & & & & & 13.08 \\
\hline
\end{tabular}

sections of the study area. The ANOVA Table 17 reveals that calculated $\mathrm{F}$ statistic value for the analysis is 0.000127 while the critical value is 3.31583 . Therefore, since the calculated $F$ statistic value of 0.000127 is less than the critical value of 3.31583 at $\mathrm{F}^{2} 32$ degree of freedom, the null hypothesis $\mathrm{H}_{0}$ of no significant variation is accepted and the alternate hypothesis $\mathrm{H}_{1}$ is rejected. The result of the study revealed that there is no statistically significant variation in air quality in the different sections of the study area.

The second study hypothesis $\left(\mathrm{H}_{02}\right)$ states that there is no statistically significant impact of air quality on environmental quality; this was tested with the aid of the Chi-Square statistical tool: $\mathrm{df}=(\mathrm{R}-1)(\mathrm{C}-1)=(4-1)(1-1)=$ 3 . Since the critical Chi square value at $95 \%$ significant level against 3 degrees of freedom gives the value of 7.81 , the calculated Chi square value of 107.67 is greater than the critical Chi square value of 9.49; therefore, the null hypothesis of no significant impact was rejected and the alternate hypothesis which states that there is a statistically significant impact of air quality on environmental quality was accepted.

The third study hypothesis $\left(\mathrm{H}_{03}\right)$ states that there is no statistically significant impact of air quality on health of residents at the vicinity of the Port Harcourt airport road dumpsite: $\mathrm{df}=(\mathrm{R}-1)(\mathrm{C}-1)=(4-1)(1-1)=3$. Since the critical Chi square value at $95 \%$ significant level against 4 degrees of freedom gives the value of 7.81 . The calculated Chi square value of 13.08 is greater than the critical Chi square value of 7.81 ; therefore, the null hypothesis of no 
significant impact was rejected and the alternate hypothesis which states that there is a statistically significant impact of air quality on Health was accepted.

\section{DISCUSSION}

This study was carried out to examine environmental and health risk implications of air quality in the vicinity of the Port Harcourt airport road dumpsite. In order to achieve the aim of the study, some objectives as well as research questions were raised which the present study provided explanations for. Therefore, this discuss is made in the light of the study objectives.

The first objective of this study was to determine the air quality in the vicinity of the Port Harcourt airport road dumpsite, this was done with the aid of some equipment, which measured the different air quality parameters highlighted as reported in Table 1 of the study. It was discovered that amidst all the parameters measured in the different sampling locations, Nickel and chromium were higher than the acceptable limits while other parameters were within.

This however revealed that the air in the vicinity of the waste dump was polluted owing to the fact that the parameters of concern where not all within the acceptable World Health Organization Standard for air quality, hence is termed polluted. The effect of breathing this polluted air, on regular basis for a long time has exposed the residents within the study area to different detrimental health challenges. The findings of this research are in tandem with previous researches by the likes of Chukwu-Okeah et al. (2019), Igboji and Joseph (2015), Vincent and Obisesan (2014) and Agwu and Ozeh (2013).

The second study objective was to examine the health risk implications of air quality in the study location. Response from the questionnaire analyzed as shown on Table 8 revealed that waste dumpsite in the area influences air quality, this was agreed to by an overwhelming $69.2 \%$ of the respondents. This finding is also in line with Ezekwe and Arukoyu (2017), Ubouh et al. (2016), Allen et al. (2015) and Committee on Environmental Health (2004).

In Table 9, ailments arising from the presence of the dumpsite as revealed have upper respiratory tract infection (URTI) and rashes topping the list with a whopping $62.7 \%$ response rate from respondents. This however provides an evidence of the health implications of the waste dumpsite. This is also in line with the works of Ochindo (2015), Brauer et al. (2008) and Bell et al. (2004).

The third objective however was to ascertain the environmental implications of air quality in the vicinity of the Port Harcourt airport road dumpsite. Response from the questionnaire analysed as showed in Table 10 revealed that a total $90.4 \%$ of the respondents agreed that air quality in the vicinity of the waste dump influences environmental quality of the area. In Table 11 also, $61.6 \%$ of respondents agreed that the presence of waste dump in the vicinity is an environmental nuisance, this is in agreement with the work of Ezekwe and Arukoyu (2017), Pieters et al. (2015), Mateen and Brook (2011), Miller et al. (2007) and Hamoda (2004). In line with the above, the study further showed in Tables 12, 13 and 14 that $68.1 \%$ of the respondents agreed that the dump have deformed the land in the area, $54.2 \%$ of the respondents agreed that the location of the dump have affected property and rental value in the vicinity and $81.9 \%$ of the respondents agreed the dump has defaced the aesthetics of the area.

In the light of objective four, this was to identify if there are variations in air quality in the different sections of the study location. From the tested hypothesis in Table 17, the study shown that there is no statistically significant variation in air quality in the different sections of the study area. This also agrees with the work of Ochindo (2015), Amuda et al. (2014) and Saber and Heydari (2012).

Conclusively, the study hypothesis tested confirmed that there are impacts arising from the waste dumpsite on health and environment which however explains that there are environmental and health implications in the vicinity of the Port Harcourt airport road dumpsite. However, the findings of the study include:

1. Nickel and Chromium amongst other parameters measure were above the WHO set limit, hence the air was termed polluted.

2. URTI and rashes are prominent ailments that are prevalent in the area.

3. There is an evidence of the health implications of the waste dump on residents.

4. Air quality influences environmental quality in the waste dump vicinity and that the presence of waste dumpsite in the vicinity is an environmental nuisance.

5. There is no statistically significant variation in air quality in the different sections of the study area.

6. There are impacts arising from the waste dumpsite on health and on the environment, which, however, explains that there are environmental and health implications in the vicinity of the Port Harcourt airport road dumpsite.

\section{Conclusion and recommendations}

From the results, it is clear that the citing of the waste dumpsite in the study location was a wrong idea having in mind that the area is developing residential area. This however explains the neglect of urban planning policies and regulations in the city of Port Harcourt. The findings have shown the state of the environment and health of residents around the vicinity of a typical municipal solid waste dumpsite. Therefore, this research recommends that:

1. Proper urban planning should be done, especially, in citing of new dumpsites. The process should include 
integrated development plan of appropriate land use, environmental impact assessments and adopting standard regulatory processes.

2. Government should be advised that where waste dumps are cited, residential apartments should not be located within $3 \mathrm{~km}$ radius of the dumpsite.

3. In view of the health challenges and other environmental impacts observed around the vicinity of the Port Harcourt airport road dumpsite, the dumpsite should be closed, in order to forestall further deterioration of the health of the resident community and other environmental damages.

4. Since this research was conducted in one dumpsite, further research efforts should be conducted with the aim of evaluating the impacts of all the dumpsites within Port Harcourt City, on the environment and the health of the proximate communities.

\section{CONFLICT OF INTEREST}

The authors declare that they have no conflict of interest.

\section{REFERENCES}

Agunwamba, J. C., Egbuniwe, N., Ugwu, F. I. (2006). Characteristics of pollutants in waste dumpsite. International Journal of Environment, 8(1and 2),184-192.

Agwu, A., \& Ozeh, R. N. (2013). Evolution of ambient air: Quality of Aba Metropolis, Nigeria. International Journal of Current Research, 5(4), 843-844.

Allen, J G., MacNaughton, P., Satish, U., Santanam, S., Vallarino, J., \& Spengler, J. D. (2015). Associations of cognitive function scores with Carbon Dioxide, ventilation, and volatile organic compound exposures in office workers: A controlled exposure study of green and conventional office environments. Environmental Health Perspectives, 124(6), 805-812.

Amuda, S. O., Adebisi, S. A, Jimoda, L. A., \& Alade, A. O. (2014). Challenges and possible panacea to the municipal solid wastes management in Nigeria. Journal of Sustainable Development Studies. 6(1), 64-70.

Bell, M. L., Davis, D. L., \& Fletcher, T. (2004). A retrospective assessment of mortality from the London smog episode of 1952: The role of influenza and pollution. Environmental Health Perspectives, 112(1), 6-8.

Brauer, M., Lencar, C., Tamburic, L., Koehoorn, M., Demers, P., \& Karr, C. (2008). A cohort study of traffic-related air pollution impacts on birth outcomes. Environmental Health Perspectives, 116(5), 680-686.

Brudtland Commission (2007). Our common future: World Commission on Environment and Development Stockholm.

Chukwu-Okeah, G. O, Imiete, G., \& Obidininwa, F. C. (2019). Air quality and health of cement dealers in Obio/Akpor Local Government Area of Rivers State, Nigeria. Asian Journal of Applied Sciences, 12(1), 22-28.

Committee on Environmental Health (2004). Ambient air pollution: Health hazards to children. Pediatrics, 114(6), 16991707.

Ezekwe, I. C, Agbakoba, C, Igbagara, P. W. (2016). Source gas emission and ambient air quality around the Eneka co-disposal landfill in Port-harcourt, Nigeria. International Journal of Applied Chemistry and Industrial Sciences, 2(1),11-23.

Ezekwe, I. C., \& Arukoyu, S. B. (2017). Landfill Emissions and their Urban Planning and Environmental Health Implications in Port Harcourt, South-South Nigeria, Desenvolv. MeioAmbiente, 42, 224-241.

Hamoda, M. F. (2004). Air pollutant emissions from waste treatment and disposal facilities. A paper presented at Dubai International Conference on Atmospheric Pollution, Dubai, U.A.E., February 21-24.

Igboji, O. P., \& Aloh, J. (2015). Indiscriminate dumping of wastes contributes to air pollution in Abakaliki, Southeast Nigeria. American-Eurasian Journal of Agricultural and Environmental Science, 15(11), 2282-2288.

Igwe, T. S., Njoku, C., Ogenyi, T. E. (2013). Effect of industrial emissions in atmospheric environment in South East Nigeria; New Era Research Journal of Human, Educational and Sustainable Development, 6(4), 1-7.

Kevin, L. (2018). The importance of air. Retrieved 24th August, 2018 from https://sciencing.com/importance-air-6330367.html

Mateen, F. J., \& Brook, R. D. (2011). Air pollution as an emerging global risk factor for stroke. JAMA, 305(12), 1240-1241.

Metz, B., Davidson, O. R., \& Bosch, P. R, (2007). Contribution of Working Group III to the Fourth Assessment Report of the Intergovernmental Panel on Climate Change. New York: Cambridge University Press.

Miller, K. A., Siscovick, D. S., Sheppard, L., Shepherd, K., Sullivan, J. H., Anderson, G. L., \& Kaufman, J. D. (2007). Longterm exposure to air pollution and incidence of cardiovascular events in women. New England Journal of Medicine, 356(5), 447-458.

Millican, C., \& Barker, M. (1997). GCSE Biology. Harlow: Addison Wesley Longman Limited. ISBN 0582-30481-4.

Njoku, C (2015) Effect of waste dumpsites on water and air qualities in Abakaliki, Southestern Nigeria. International Journal of Plant and Soil Science, 4(5), 455-460.

Ochindo, S. O. (2015). Assessment of air quality in the vicinity of fertilizer plant in Onne. An Unpublished M.Sc Thesis, University of Port Harcourt.

Ogolama, S.C. (2012) Assessment of health risk behaviours of oil servicing company workers in Port Harcourt. An Unpublished M.Sc Thesis, University of Port Harcourt.

Ogunji, J. O., Okogwu, O., \& Mgbeafuruike, J. (2004). Environment biology and waste management principles. Ruga Enterprises; Enugu.

Osuiwu, B. O., \& Ologunorisa, T. E. (1999). Weather and climate in Port Harcourt region. Oyegun, C. U., \& Adeyemo, A. (eds). Paragraphics, Port Harcourt.

Pieters, N., Koppen, G., Van Poppel, M., De Prins, S., Cox, B., Dons, E., Nelen, V., Panis, L.I., Plusquin, M., Schoeters, G., \& Nawrot, T. S. (2015). Blood pressure and same-day exposure to air pollution at school: associations with nano-sized to coarse PM in children. Environmental Health Perspectives, 123(7), 737-742.

Rim-Rukeh, A. (2014). An Assessment of the contribution of municipal solid waste dump sites fire to atmospheric pollution. Journal of Air Pollution, 3(3), 53-60.

Saber, E. M., \& Heydari, G. (2012). Flow patterns and deposition fraction of particles in the range of $0.1-10 \mu \mathrm{m}$ at trachea and the first third generations under different breathing conditions. Computers in Biology and Medicine, 42(5), 631 638.

Ubouh, E. A., Nwawuike, N., \& Ikwa, L. (2016). Evaluation of the on-site and off-site ambient air quality at Nekede waste 
dumpsite, Imo State, Nigeria. British Journal of Earth Sciences Research, 4(1), 18-22.

US-EPA (1999). National Emission Standards for Hazardous Air Pollutants for Source Categories. Cement Manufacturing Industries, Federal Register. 64, 113.

Vincent, E. W., \& Obisesan, A. (2014). Air quality in the vicinity of a landfill site in Rumuolumeni, Port Harcourt, Nigeria. Journal of Environment and Earth Science 4(10), 9p.
WHO (2014). Seven million premature deaths annually linked to air pollution. Retrieved 24 August 2018 from https://www.who.int/mediacentre/news/releases/2014/airpollution/en/. 